COMMENT

Check for updates

https://doi.org/10.1057/s41599-020-0428-1

\title{
Monsters: interdisciplinary explorations in monstrosity
}

Sibylle Erle (iD ${ }^{1,2 \times} \&$ Helen Hendry ${ }^{1,2}$

\section{ABSTRACT}

There is a continued fascination with all things monster. This is partly due to the popular reception of Mary Shelley's Monster, termed a 'new species' by its overreaching but admiringly determined maker Victor Frankenstein in the eponymous novel first published in 1818. The enduring impact of Shelley's novel, which spans a plethora of subjects and genres in imagery and themes, raises questions of origin and identity, death, birth and family relationships, as well as the contradictory qualities of the monster. Monsters serve as metaphors for anxieties of aberration and innovation (Punter and Byron, 2004). Stephen Asma (2009) notes that monsters represent evil or moral transgression and each epoch, to speak with Michel Foucault (Abnormal: lectures at the Collège de France, $1975-75,2003$, p. 66), evidences a 'particular type of monster'. Academic debates tend to explore how social and cultural threats come to be embodied in the figure of a monster and their actions literalise our deepest fears (Gilmore, 2009; Scott, 2007). Monsters in contemporary culture, however, have become more humane than ever before. Monsters are strong, resilient, creative and sly creatures. Through their playful and invigorating energy they can be seen to disrupt and unsettle. They still cater to the appetite for horror, but they also encourage us to feel empathy. The encounter with a monster can enable us to stop, wonder and change our attitudes towards technology, our body and each other. This commentary article considers the use of the concepts of 'monsters' or 'monstrosity' in literature, contemporary research, culture and teaching contexts at the intersection of the Humanities and the Social Sciences.

\footnotetext{
${ }^{1}$ Bishop Grosseteste University, Lincoln, UK. ${ }^{2}$ The Open University, Milton Keynes, UK. ${ }^{{ }}$email: sibylle.erle@bishopg.ac.uk
} 


\section{Introduction}

- he reception of Mary Shelley's Frankenstein (1818) offers many opportunities for academic research to intersect with popular culture. Frankenstein has become a significant cultural reference point. Indeed, responses to Shelley's novel have proliferated across a range of genres and media since its publication and continue to spawn contemporary reactions. In the twentieth century, these include sequels (Myers, 1975) and retellings (Ackroyd, 2008; Aldiss et al., 2016), as well as the use of the name 'Frankenstein' as a token for horror in subsequent novels from the 1950s onwards (Carrière, 2016). Performance adaptations started with Presumption; or, the Fate of Frankenstein, written by Richard Brinsley Peake, first shown in London in 1823 and the most recent is Liam Scarlett's adaption for the Royal Ballet (ROH, 2019). Frankenstein has also inspired many movies with the Monster being portrayed as a grotesque, an innocent and a source of humour, further influencing a range of film hybrid genres, such as Science-Fiction Horror (Picart, 2003). The novel has been considered as a pre-cursor to Science Fiction (Seed, 1995), it has been interrogated through feminist approaches (Hodges, 1983), queer theory (Rigby, 2009), and in the context of the Gothic as well as in examinations of slavery and racism where Frankenstein functions as a metaphor to politically critique discourses of power, identity and nature with (Sterrenburg, 1979; Collings, 2009; Mulvery-Roberts, 2016; Young, 2008). Analysis of Frankenstein's Monster has led to discussions of new forms of humanity and reflections on social relations as well as gender (Hedrich-Hirsch, 1996; Creed, 1993). ${ }^{1}$

The range of literary perspectives and multidisciplinary connections across this special collection brings into focus the pertinent theoretical and methodological challenges relating to how the monstrous finds application not only in critical thinking but also in teaching contexts. Monsters, despite any kind of reservation, have a lot to offer. When it comes to defining 'monster' and 'monstrosity', Foucault in his lectures on the Abnormal (2003) differentiates between three, different figures: one, the 'human monster', i.e., someone or something who has the 'capacity to create anxiety [...] due to the fact that it violates the law [...] by its very existence' (p. 56). Two, the 'individual to be corrected', so that they confirm with the law, and three, specifically the 'masturbator' who breaks moral law. Foucault, in his archaeology of the Abnormal, reviews the shifting relations between the normal, the abnormal and the sexually deviant to explain the transgressive quality and moral challenge embodied by the monster, which, in Foucault's words, is 'a monstrosity of conduct rather than the monstrosity of nature' (p. 73). The issue here is the normative approach to the human condition. This collection is, in the first instance, concerned with the relationship between figures one and two which Foucault explains thus:

The monster's frame of reference was nature and society, the system of laws of the world: the monster was a cosmological or anticosmological being. The frame of reference of the individual to be corrected is much narrower: it is the family exercising its internal power or managing its economy, or, even more, in its relations with the institutions adjoining or supporting it. (p. 57)

For our purposes, the combination of the categories ('human monster' and 'individual to be corrected') raises the question of what is acceptable or desirable in human beings as well as in social contact. Turning to these questions from within a literary framework, we note that English Literature abounds with monsters, ranging from Grendel to Voldemort. Monsters are also familiar figures from our consumption of Greek myths, Ovid's Metamorphoses and, of course, Fairy Tales. Monsters in all these stories must be fought and victory tends to be conquest followed by relief or emotional stillness. After the fight the protagonist, to regain his humanity, has to let go of everything (monstrous), everything they used to conquer the opposing force with (Botting, 2008). Only then will they have grown and only then can they embrace their new, better self and start afresh. Traditionally, the figure of the monster has been used to measure the status of 'the human' both in terms of appearance and ethical choice or agency. Conflict exists and inappropriate behaviour needs to be addressed to improve and guarantee the functioning of human relations as well as political systems. What does it mean to be human? This question has been posed continually in Literature but also in the context of Education, particularly through curriculum discourse in Religious Education (R.E.), Citizenship and Personal Social and Emotional education (P.S.I.). It is all the more pertinent in an age in which we talk about the post-human, which includes hybrid human and technological modes of life and living. School is one site where the nurturing of human values and attempts to form or rather transform society for the better commence. In a time of societal change, the application and integration of technology is often perceived to be a threat to human integrity, as well as to emotional relations between human beings. Furthermore, at a time of conflict and division in politics and society in the UK and beyond, groups of diverse perspectives, religions and cultures can be 'othered' in a way that they become regarded as monstrous (Struthers, 2017; Kenny and Ghale, 2015). This othering is both constructed and contested by some educational opportunities and expectations. More often, monsters represent the unfamiliar and threatening and sometimes the soulless and inhuman.

Where does 'the monster' end, and where does 'the human' start? The boundaries between these categories are fluid as the description of research on Shelley's Frankenstein below will indicate. In The Order of Things (2005) Foucault outlines the function of monsters and functioning of monstrosity for the concept of 'the human' and, quoting Foucault, Fred Botting (2003) delineates the cultural significance of monsters thus:

There are two natures disclosed by monsters: that which is ordered, classified and regulated by scientific discourse, and that which remains undifferentiated, in process. Monsters from the point of articulation between the two, located as part of the undifferentiated murmur or noise of natural process and marked out in the identification of proper and recognisable species: 'on the basis of the continuum held by nature, the monster ensures the emergence of difference' (cited in Foucault, 2005, 156). (p. 344)

Botting, like Foucault before him, deliberates classification. His neat summary should not take away from the fact that monsters -by their very nature-confront us with excess, a circumstance, which strictly speaking should make classification impossible. However, as Botting suggests, the use of 'monster' as metaphor enables the interrogation of social or intellectual problems: monsters embody fear or excitement and monstrosity represents amoral or uncontrolled behaviour. All is channelled into emotional expression through language and in particular through metaphor. Monsters, in addition, put into words feelings that we struggle to express ourselves. A metaphor, to return to Foucault however, can really only be an indirect approach to a challenge or social problem, one which falls into the 'regime of silence' or within the realms of 'censorship' (2003, p. 70). This means that monsters are often mysterious because they represent what cannot be articulated. Foucault, moreover, viewed education itself as a monstrous force of power and discipline, which enacts control over the transgressive intents of childhood (Deacon, 2006, p. 184). Similarly, institutional racism, labelling and othering of pupils and families also highlight the Foucauldian perspective in 
which 'the natural' is made monstrous by society (Harwood et al., 2014). As a phenomenon, consequently, monsters or monstrous acts can prompt the impulse to imagine new social relations both during the reading and teaching processes.

\section{The afterlife and legacy of Mary Shelley's Frankenstein}

Shelley's novel engages with questions of origin as well as identity via the complex relationship between Frankenstein and the Monster (Smith, 2016). The 1818 edition (now the preferred teaching text) never reveals how Frankenstein made his monster or indeed animated its lifeless body. Only in the introduction to the third edition, published in 1831, did Shelley mention 'galvanism' (Baldick, 1987, p. 4; Vasbinder, 1984, pp. 32-37). This scientific practice, which needs to be contextualised with the Enlightenment discourse of progress as well as the Industrial Revolution, harks back to the experiments of the Italian physician and philosopher Luigi Galvani (1737-1798), who used electric currents and discovered their electro-magnetic effect on frog legs. Galvani saw the muscles of dissected animal limbs contract (Turney, 1998, pp. 19-22). It appears that it is due to Shelley's belated explanation that Frankenstein has become the epitome of the mad scientist, as well as a shorthand for advances in science or technology gone wrong. Shelley, furthermore, refines much of her description of Frankenstein's character in the 1831 version of the text. In 1818, the narration and its handling of point of view is delicately balanced, allowing both creator and creation to emerge as heroic. In 1831, self-torture and histrionic regret dominate the delineation of Frankenstein's inner life. About Shelley's rewriting and the shift from scientific break-through to moral disaster, Marilyn Butler writes: 'her alteration were acts of damagelimitation rather than a reassertion of authority' (1993, p. 313): 'in 1831 Mary Shelley added long passages in which her main narrator, Frankenstein, expresses religious remorse for making a creature, and it is on such passages of reflection and analysis that the empathetic modern reader is encouraged to dwell' (p. 303). While the Monster is of nature as it is a walking assemblage of corpses, it is also beyond nature because it is badly made by someone who acts outside nature. This creature is not born (Huet, 1993) and Frankenstein has made many claims about his probing deeply into the secrets of life; he deems himself able to master natural laws. The Monster, to be clear, is ugly but kind and these qualities coexist throughout the story. To explain the Monster's complex beginning from a Feminist perspective scholars have turned to Shelley's life-story, and, in particular, the themes of death, birth and family relations, in an attempt to explain the motivation behind some of her artistic choices (Mellor, 1980).

Frankenstein has a resonating cultural presence. Why has Shelley's story been so successful? In view of the existing interpretations, the reason appears to be two-fold: one, the theme of monstrosity, i.e., the impact of Frankenstein's disastrous creation and abandonment of his creature (Bann, 1994), and two, monstrosity as writing process (Clark et al., 2001), i.e., Shelley's artistic conception of a novel that blends disciplines and twists genres. The story has also a great number of historical reference points. Shelley implies the context of Romantic science (Shelley, 1994; Mitchell, 2013) and includes quotations from John Milton's Paradise Lost, Samuel Taylor Coleridge's 'The Rhyme of the Ancient Mariner' and William Wordsworth's 'Lines written a few miles above Tintern Abbey'. The patching together of texts (as well as body parts) is characteristic of the Gothic and Judith Halberstam, whose Skin Shows (1995) combines Foucauldian reading with psychoanalytic interpretation, comments that monstrosity is foremost textual: 'multiple interpretations are embedded in the text and part of the experience of horror comes from the realisation that meaning itself runs riot' (p. 2). Gothic texts are layered and purposefully construct different meaningsystems whose contradictions are suspended rather than resolved. The role of the monster, consequently, can be part of a multifaceted signifying net and multimodal; it 'condenses', she writes, 'various racial and sexual threats to nation, capitalism, and the bourgeoisie into one body' (p. 3).

Frankenstein's Monster has no name. It is referred to as 'monster', 'wretch', 'daemon', 'creature' and 'fiend' (Baldick, 1987, p. 10) and in her novel Shelley uses the word 'creature' (nowadays a popular name for the Monster) to refer to other characters. However, ever since Nick Groom's edition of Frankenstein (2018) 'being' appears to be the correct or rather the most acceptable term for Frankenstein's creation. This is regardless of anyone's personal preference. The gravitation towards a term that evokes this figures victimhood leads us to the symbolic power of naming, because what Frankenstein's creation is depends on what we call it (Lacan, 1966). Interestingly, and this tends to happen frequently, the names of creator and creation get mixed up. This confusion dates back to the nineteenth century and has long since invited the concept of a double-being and literary device of Doppelgänger and the conclusion that Monster is a projection and that Frankenstein is the real monster. The physical reality of the Monster's deformed body, on the other hand, cannot be ignored. To quote Baldick: 'the novel provides no explanation for the creature's ugliness, and if we are tempted to account for it psychologically as a mere projection of Frankenstein's guilty revulsion of his dead, we run up against the evidence of the other character's reactions' (p. 33). The Monster is a real enough entity and albeit its freedom to disobey fascinates, a better understanding of the reasons behind its monstrous acts does not necessarily lead to a defeat of fear. The reason being that the permeable boundary between 'the human' and 'the monstrous' never settles (Feder, 2010). The Monster may not look like Frankenstein but they are definitely connected (Botting, 2008). Shelley explores this through the Monster's reading to Paradise Lost and its consequent identification with Adam and Satan (Cantor, 1984; Newlyn, 1992). Through this shift in selfperception Shelley presents deformity as difference in the force field of natural philosophy, as well as religion (see Foucault, 2005). She delves deeply into the deviant anatomy of the human body (Youngquist, 2003). The Monster cannot fit in and its hybridity, bearing in mind that Frankenstein united human with animal parts, speaks strongly against a place in God's creation even though it is a perfect artwork before it starts to move. This means that Frankenstein's Monster is an object of desire as well as disgust (Wright, 2018; Erle, 2018b). Frankenstein wanted to create a new species but he terminates its future when he breaks his promise and aborts the female monster, which is Frankenstein's ultimate act of monstering. He socially isolates the Monster. The Monster's response, however, is so familiar, so human. It is angry and demands revenge and justice.

Monsters are familiar and part of everyday life (Canguilhem, 1962; Auerbach, 1995; Botting, 2008). However, Frankenstein's Monster is special because Frankenstein formulates the tensions arising between nature and nurture as well as self and society (Gilbert, 1978, pp. 59-63). Monstrosity in Frankenstein is not only associated with appearance but also with actions: Frankenstein's creation is a killer. In spite of this fact there exists a tendency to explain away its monstrous acts with neglect or bad treatment. The Monster kills Frankenstein's youngest brother William but is not to blame because it was abandoned by its maker; it is a victim and we-readers of Shelley's novel-should feel compassion and, according to a recent newspaper article, most of our current students do (O'Shea and Jacobs, 2018). This move towards more empathy implicates the reader in new and 
interesting ways. Should we understand and ultimately forgive absolutely everything? This collection starts with the premise that Shelley's monster is not only larger than life, it has also assumed a life outside the novel. The collection, consequently, wants to position Shelley's Frankenstein beyond its immediate Gothic and literary contexts. The meaning of the monster is in the eye of the beholder and therefore they can be therapeutic, familiar, reassuring as well as evil. Monsters do not always repulse nor do monstrous acts always evoke fear and disgust (Wright, 2018), which is why they are connected to a whole range of disciplines, such as architecture, counselling, drama, ecocriticism and children's literature.

\section{Monster theory and monster studies}

In his foreword to The Ashgate Research Companion to Monsters and the Monstrous (2012) John Block Friedman, author of The Monstrous Races in Medieval Art and Thought (1981) proclaims that monsters are 'ubiquitous [...] [they] are all around us, in our dreams our children's reading, in accounts of postcolonial capitalism and exploitation and films detailing the power relations between men and women, in our perceptions of disabled people in the streets; sometimes, even, they are us' (xxvii). The Ashgate Companion, consequently, gives an extremely useful overview of monster traditions and in his introduction Asa Simon Mittman justifies the existence of Monster Studies, emphasising impact over qualities of monsters: 'the defining features cannot be considered essential, as it were, as the sources are too varied, to wonderfully divergent to be summarised or contained by such characteristics' (p. 9). Regarding impact, which results in a change in attitude towards difference, Patricia McCormack's definition of 'encounter' is helpful: 'The Monster' refers to the element outside the observer that sparks and creates an event of perception that necessitates the participation of two unlike entities.' A monster, she writes, is 'a catalyst toward an encounter' (2012, p. 294) and this 'encounter' is productive. Consequently, what is unacceptable because it is morally transgressive can still suggest new possibilities for human interaction. In this sense, it was our aim for this collection to juxtapose different approaches which, we hope, will facilitate a dialogue between the Social Sciences and the Humanities.

What makes a monster 'a monster'? Jeffrey Weinstock explains that monsters 'are things that should not be, but nevertheless are -and their existence raises vexing questions about humanity's understanding of and place in the universe [...]. The Monster', he writes, 'undoes our understanding of the way things are and violates our sense of how they are supposed to be' (2014, 1 and 2). Foucault, when defining these categories, emphasised the quality of mixing or 'blending' of species, sexes and forms (2003, p. 63). His definition acknowledges that the notion of a true or authentic self is a construction; it is indeed problematic on the basis of lived experience to insist that one gender or one race are enough to categorise human beings with. If we, however, treat 'monsters' or 'monstrosity' as fear projected on to another, then 'otherness' comes to include all those traits (of us as individuals or a society), which we know exist but refuse (consciously or subconsciously) to acknowledge (Kearney, 2013). Halberstam, too, pays tribute to the psychoanalytic dimension of monsters as a category for conceptualisation, when summarising the trends in scholarship on Horror, and in particular in relation to Freud's Studies on Hysteria (1995, pp. 18-20). Barbara Creed, in turn, investigated the connection between the female and the monstrous (1995). Mitman, by comparison, asks a simple but potent question which entirely discards the Gothic and ignores any literary conventions to do with the supernatural. To paraphrase Mittman: does the fact that people believe in monsters make them 'real' (p. 4)? Mittman then traces this phenomenon (the apparent reality of monsters) back to Jeffrey Jerome Cohen's Monster Theory: Reading Culture (1996), one of the founding texts of Monster Studies (Cohen argued that monsters were a product of culture, functioned as signs and symbols for societal problems and demanded to be acknowledged on account of their mere presence). Mittman essentially suggests that when we experience monsters through the emotional effect ('impact') they have on us, they become a physical reality for us (p. 4). This is, we think, why monsters are both a metaphor and a tool to tackle the moral and ethical consequences of science's potential to enhance life and human agency (Ryder, 1990).

One reason for the continuing fascination with Frankenstein is its othering of creator and creation and the uncertainty this act of separation brings about. It links to the fear of losing status, which, as stated above, is caused by shifting boundaries between self ('the human') and other ('the monstrous'). With regard to enhancement, which is of course Frankenstein's starting point, improvement can also be perceived as other. Fear, it seems, is caused by technological determinism, which is only hinted at in the novel of 1818 but developed through the reception process. So, where do we draw the line? Georges Canguilhelm (1962), for whom monstrosity was primarily a biological concept, argues that to be a monster, the thing has to be alive: 'the qualification of monster must be reserved for organic beings. There is no such thing as a mineral monster. There is no such thing as a mechanical monster' (p. 28). The monstrous quality of life comes to the fore in Frankenstein's laboratory and at the very moment the new species opens its eyes. Frankenstein overreacts but he does come to his senses; he recognises that he has created a monster and that he is unable to handle it. A monster is always alive and, therefore, a negation of human values and, therefore, 'valuable only as a foil'. Canguilhelm writes further: 'by demonstrating how precarious is the stability to which life has accustomed us-yes, only accustomed, but we made a law out of its custom - the monster gives an all the more eminent value to specific repetition, to morphological regularity, to successful structure; it makes us realise that these are not necessary' (p. 29). We have come a long way (see McNally, 2011). The imaginings of what can count as 'normal' and by default 'human' have since incorporated enhancement of potential through the discourses of robotics and artificial intelligence and in Science Fiction. Medical science can now delay death and digital technologies appear to enable us to plan our afterlives. The moral and ethical implications of this paradigmatic shift in human existence are obvious. We may decide to think of the dead version of ourselves as monstrous.

Frankenstein is part of discussions of the post-human condition. In this context, the question of what it means to be human contests with the transformative powers of technology, which are either welcomed as an extension or dreaded as an invasion (Zylinska, 2002; Szollosy, 2017). Analysis and critical framing of the technological evolution and consequences for human relations is in Donna Haraway (1991), Bruno Latour (1993), Chris Hables Grey (1995) and Elaine Graham (2002). Reviewing the existing literature, Graham (2004) notes 'contemporary technology [...] will shape our understandings of what it means to be human into the next century. For embedded in the various technologies are crucial issues of identity, community and spirituality' (p. 12).

The flourishing interpretations of the relationship between Frankenstein and the Monster speak of of changes in culture. What qualifies as a monster has been thrown into relief through the shift in appreciation of the problems the monster embodies (McNally, 2011). Frankenstein's Monster is a hybrid because it is not born but made with 'instruments of life'. Technology is transformative, not neutral, but still the ever so important story of 
origin remains vague because Frankenstein never specifies what these 'instruments' are. Shelley may have given an explanation in the introduction to the 1831 edition (Hitchcock, 2007), but 'instruments of life' and 'spark of life', which can be read as either electrical spark or indeed soul, is all the novel gives; to start with, body and soul were not separated, at least in the Greek tradition. Today it is the priest who deals with the soul and the undertaker who deals with the body. It is perhaps through the movies and Hollywood adaptations that the laboratory scene, that ur-story told on Lake Geneva in 1816, has been fleshed out, as well as repositioned within different critical frames. In the novel, it is when the Monster starts to move, according to Frankenstein, that everything changes (Erle, 2018a). The so-called creation scene appears to equip the Monster with a body as well as feelings. Frankenstein's creature resembles no one but it tries to bond. Frankenstein, however, cannot bear the sight of it; he rejects and abandons it. The Monster later articulates its need for affection and attempts to come to an agreement with his maker; its request for a partner is eventually denied on account of the potential monstrousness of that future partner and yet, it is most likely that it is the pleading with its master and subsequent disappointment that transforms this monster from an 'it' into a 'he'. Frankenstein has referred to his creation as both 'he' and 'it', designations, which reflect his ambivalence, and with the narrative unfolding and points of view complementing each other, Frankenstein's creation becomes more and more familiar. He has real, recognisable needs and desires. Frankenstein's decision, his sudden moral qualms or realisation that he ought not to go ahead however, condemns his creature to utter loneliness. Frankenstein's Monster is on his own forever. Popular culture, on the other hand, teems with monsters and many of them can keep each other company.

\section{Monsters in teaching contexts}

Popular cultural representations of monsters include their ubiquitous presence in children's literature. Monsters are therefore an important part of children's lives through reading and storytelling both within the classroom and at home. Like Frankenstein, the monsters of children's literature are often multi-faceted, with their motives and imagery open to interpretation. They can represent fears of children and adults, the child protagonist's alter ego, or inner-self, or even be an interesting subject of analysis as a character with their own needs and challenges (Papazian, 2014). For these reasons, discussion of monsters and the monstrous in children's literature provides an obvious vehicle for teachers to connect to curriculum and teaching about personal, social and emotional issues, character and motivation. For example, monsters can be a focus for considering relationships, differences, bullying and overcoming fears. Rather than using texts as a way of teaching a directive moral lesson, a socio-cultural approach to teaching emphasises that children and young people learn through participation or 'dialogically' constructing their own meanings and understanding through discussion with others (Alexander, 2008; Cox, 2017). Children's literature offers a unique and flexible place for such construction. Furthermore, 'monstrous' visions of the future and societal change presented through dystopian young adult fiction such as The Hunger Games (Collins, 2009) and picture books or animated shorts such as 'Varmints' (Craste and Ward, 2013) allow teachers to open sensitive discussion about challenging concepts and issues, including human rights, democracy and conflict:

Such narratives play upon deep, unresolvable fears from 'reality,' exaggerating (and sometimes solving) them in fictional scenarios. In the case of young adult dystopia, it is the young people-willing or not-who must confront these fears and ultimately solve the problems that spawn them (Ames, 2013, p. 6).

Ames argues that these texts offer a way of connecting pupils with political and social challenges in an environment that is safely removed from their real lives. These teaching possibilities are particularly important when pupils witness conflict and division in the media and day to day lives or are coping with making sense of conflicting perspectives on challenging issues such as gender identity and the treatment of refugees (Woolley, 2010; Hope, 2018).

Children and young people's mental and emotional health and well-being are a significant area of concern for health services, families, educators and policy makers (NHS Digital, 2017; Patel et al., 2007; PHE, 2016; PSHE Association, 2019). This topical concern links to the use of monster characters in fiction as a possible teaching tool, as PSHE guidance emphasises that 'distancing' learning about sensitive issues by using fictional characters could help pupils to engage with the topic rather than becoming overwhelmed by their own emotional responses. Similarly, the threat and opportunity of technological change looms large in teaching contexts where teachers and pupils must navigate the creative potential of cyber-space with caution (DfE, 2019; UKCIS, 2018). Schools must equip pupils to avoid 'monstrous', transgressive uses of technology as either recipients or participants and this too can be raised through literature, for instance in Penguinpig (Spendlow, 2014), the tale of a little girl misled by the internet to search for an unobtainable creature.

Themes emerging from connections with Frankenstein in teaching contexts move beyond using monstrous imagery and characters in children's literature to spark discussion. There are many more monstrous issues that influence research and debate about education itself. In England, the terminology of 'British Values' and the expectation to uphold these as part of the standards for qualified teachers (DfE, 2011) is felt by some to connect 'British Values' with whiteness and demonise people of 'nonBritish' origin, setting up a false division and potentially encouraging a backlash against ethnic minority cultures (Maylor, 2016; Phillips, 2010). Furthermore, the 'Prevent' duty placed on schools to monitor and report concerns about pupils at risk of radicalisation has been noted to be socially divisive and create a particularly negative focus on Muslim pupils, potentially 'othering' them within school communities (Kenny and Ghale, 2015; Lumb, 2018). Similarly, but affecting both the UK and beyond, interest in the power of education to address social disadvantage and disparity in pupil outcomes has led to the development of character and resilience education (Paterson et al., 2014). In some cases, this has focused on what McDermott and Nygreen (2013, p. 93) call 'new paternalism':

New-paternalist schools promise to reduce social inequality by teaching low-income students a set of character traits and rewarding good behaviour

Originating in the USA as KIPP schools, this approach has transferred to some academies in England and emphasises discipline and a strict adherence to set behaviours, which has been described as militaristic (Lack, 2009). While there is a positive intention underlying this approach as a way of levelling the playing field' for students from less advantaged social and cultural groups, this view of character education has been criticised for unchallenged underpinning deficit assumptions about low socioeconomic status students (McDermott and Nygreen, 2013). There are also concerns about the way that character and resilience education is applied, either by ignoring pupils' fund of knowledge and attempting to eradicate cultural differences in communication in the name of 'character' (McDermott and Nygreen, 2013) 
or by pursuing the assessment of resilience as a measure of both pupil and school success (Duckworth, 2016). In this climate, monsters and the monstrous may not simply be something that teachers teach about but they may, inadvertently, be created by the educational system in which teachers function.

\section{Conclusion}

Monsters and monstrosity in literary texts and social contexts often work as a metaphor or a tool to tackle individual or social problems with. Gothic characters and themes are popular with students but have also invigorated current academic debates. They help to highlight, address as well as work through societal challenges as the range of contributions to this collection has shown. Monstrosity continues to be closely linked to the visual, which invites the question if Frankenstein's Monster would have integrated, had it lived today. When it meets and talks to the blind old man DeLacey, the Monster appears to be at ease. For once it is able to reach out and connect to another (human) being. The scene of social bonding, unfortunately, is cut short by the return of the rest of the family. There is no time to consider, remember or acknowledge the Monster's kindness towards the De Laceys. They may not have survived, if it had not been for the Monster. This leaves us with their ungrateful and monstrous behaviour. Monsters, in other words, force us to take a look at ourselves. Ideas of progress have always been twined with fear of progress, science and technology and in an age, on the brink of post-modernity, the all-enveloping claim on the so-called human essence of our identity appears to be under threat. Should we embrace or reject the changes? Time has shown that monstrous appearance and behaviour can be healed, remedied or corrected to suit cultural norms. Bodies can be operated on and personality disorders can be treated by therapists or medicated by psychiatrists. There are many options with which to enhance the bodies we have been given, as well as the connections we can forge in and beyond the communities we live in. Contemporary technology, in addition, improves human relations in that it gives better access to individual lives. These lives, on the other hand, are prone to manipulation. Photos and images can be edited and fears of losing face or a damaged reputation prevail and dominate social interaction, be it physical or real or digital or virtual. This takes us right back to Frankenstein because Frankenstein's biggest failure was to give his creation life but not a good face. By paying attention to processes and acts of monstering in teaching contexts and wider society we can learn to direct our attention towards ourselves to then empathise and re-connect with all those 'others' (Wright, 2013).

Received: 3 March 2020; Accepted: 4 March 2020;

Published online: 25 March 2020

\section{Note}

1 We are grateful to our assistant Michael Hendry who contributed to this section by researching the contemporary, popular reception of Mary Shelley's novel. Michael's research highlights Frankenstein's pervading cultural presence.

\section{References}

Ackroyd P (2008) The casebook of Victor Frankenstein: a novel. Anchor Books, New York, NY

Alexander R (2008) Towards dialogic teaching: re-thinking classroom talk, 4th edn. Dialogos, York

Aldiss BW, Moorcock M, Walker T (2016) Frankenstein unbound. Centipede Press, Colorado

Ames M (2013) Engaging "Apolitical” adolescents: analyzing the popularity and educational potential of dystopian literature post-9/11. The High School J, 9.1:3-20. Available at https://muse.jhu.edu/journals/high_school_journal/v097/97.1.a
Asma ST (2009) On monsters: an unnatural history of our worst fears. Oxford University Press, Oxford

Auerbach N (1995) Our vampires, ourselves. University of Chicago Press, Chicago and London

Baldick C (1987) In Frankenstein's shadow: myth, monstrosity, and nineteenthcentury writing. Clarendon Press, Oxford

Bann S (ed) (1994) Frankenstein, creation and monstrosity. Reaktion, London

Botting F (2003) Metaphors and monsters. J Cultural Res 7.4:339-365

Botting F (2008) Limits of horror: technology, bodies, Gothic. Manchester University Press, Manchester

Butler M (1993) Frankenstein and radical science. In: Hunter JP (ed) Frankenstein. A norton critical edition. Norton, New York, NY, pp. 302-313

Canguilhem G (1962) Monstrosity and the monstrous. Diogenes 10.4:27-42

Cantor P (1984) Creature and creator: mythmaking and English romanticism. Cambridge University Press, New York, NY

Carrière JC (2016) Frankenstein's tread. Grey Tiger, London

Clark, T, Royle, N, Bennington, G, Kamuf, P, Bennett, A \& Rooney, C (2001) "Explanations, Applications and Orientations", Monstrism (issue of experimental criticism). Clark T, Royle N (eds). In Oxford Literary Review. 23:5-31

Cohen JJ (ed) (1996) Monster theory: reading culture. University of Minnesota Press, Minneapolis

Collings D (2009) Monstrous society: reciprocity, discipline, and the political uncanny, 1780-1848. Bucknell University Press, Lewisburg, PA

Collins S (2009) The hunger games. Scholastic, London

Cox S (2017) Developing values in primary classrooms and the place of the humanities. Education 3-13 45(3):375-385. https://doi.org/10.1080/ 03004279.2017.1296925

Craste M, Ward H (2013) Varmints. Templar Publishing, Dorking

Department for Education (2019) Teaching online safety in school. Retrieved from https://www.gov.uk/government/publications/teaching-online-safety-in-schools

Creed B (1993) The monstrous-feminine: film, feminism, psychoanalysis. Routledge, London and New York, NY

Deacon R (2006) Michel Foucault on education: A preliminary theoretical overview. South African Journal of Education 26:177-187

Department for Education (DfE) (2011) Teachers' Standards Guidance for school leaders, school staff and governing bodies. Retrieved from: https://www.gov. uk/government/publications/teachers-standards

Duckworth A (2016) Don't grade schools on Grit. The New York Times. Retrieved from https://www.nytimes.com/2016/03/27/opinion/sunday/dont-grade-schoolson-grit.html

Erle S (2018a) How can I describe my emotions at this catastrophe ...?: Frankenstein, Walton and the Monster". Disbelief and romanticism. In: Andrea Tímár (ed), Special edition of AnaChronisT, New Series, 144-167. Retrieved from https://ww.theanachronist.org

Erle S (2018b) From vampire to apollo: William Blake's ghosts of the flea c. 1819-1820. In: Bruder HP, Tristanne TConnolly (eds) Beastly blake, Palgrave Studies in Animals and Literature. Palgrave Macmillan, Houndmills, pp. 225-252

Feder H (2010) 'A blot upon the earth': Nature's 'negative' and the production of monstrosity in Frankenstein. Journal of Ecocriticism 2.1:55-66

Foucault M (2005) The order of things: an archaeology of the human sciences. Routledge, London, Trans. Alan Sheridan

Foucault M (2003) Abnormal: lectures at the Collège de France, 1975-75. Picador, New York, NY, pp. 55-75. Trans. Graham Burchell

Gilbert SM (1978) Horror's twin: Mary Shelley's monstrous eve. Feminist Studies 4.2:48-73

Gilmore DD (2009) Monsters: evil beings, mythical beasts, and all manner of imaginary terrors. University of Pennsylvania Press, Philadelphia, PA

Graham E (2002) Representations of the post/human: monsters, aliens and others in popular culture. Manchester University Press, Manchester

Graham E (2004) 'Post/human conditions'. Theology \& Sexuality 10.2:10-32

Gray CH (1995) The Cyborg Handbook. Routledge, London

Halberstam J (1995) Skin shows: Gothic horror and the technology of monsters. Duke University Press, Durham, NC

Haraway D (1991) Simians, cyborgs and women: the reinvention of nature. Free Association Books, London

Harwood V, Muller J, Olssen M (2014) Foucault, power, and education. British Journal of Sociology of Education 35(6):933-945

Hedrich-Hirsch D (1996) Liberty, equality, monstrosity: revolutionizing the family in Mary Shelley's Frankenstein. In: Cohen JJ (ed) Monster theory: reading culture. University of Minnesota Press, Minnesota, pp. 115-140

Hitchcock ST (2007) Frankenstein: a cultural history. W.W. Norton, New York, $\mathrm{NY}$ and London

Hodges D (1983) 'Frankenstein and the Feminine Subversion of the Novel'. Tulsa Studies in Women's Literature 2.2:155-164

Hope J (2018) “The soldiers came to the house”: young children's responses to the colour of home. Children's literature in education. Springer Netherlands, Dordrecht, pp. 302-322 
Huet MH (1993) Monstrous imagination. Harvard University Press, Cambridge, MA

Kearney R (2013) Strangers, Gods and monsters: interpreting otherness. Reaktion, London

Kenny A, Ghale B (2015) Prevent and 'British Values'. Forum 57.2:227-229

Lacan J (1966) Écrits. Seuil, Paris

Lack B (2009) No excuses: a critique of the Knowledge is Power Program (KIPP) within charter schools in the U.S.A. Journal for Critical Education Policy Studies 7:125-153

Latour B (1993) We have never been modern. Harvard University Press, Cambridge, MA

Lumb E (2018) Terrorism in the nursery: considering the implications of the British values discourse and the prevent duty requirements in early years education, FORUM: for promoting 3-19 comprehensive education. Symposium Books, 60(3)

Maylor U (2016) I'd worry about how to teach it: British values in English classrooms. Journal of Education for Teaching 42.3:314-328

McCormack P (2012) Posthuman teratology. In: Mittman AS, Dendle PJ (eds) The ashgate research companion to monsters and the monstrous. Ashgate, Farham, pp. 293-309

McDermott KA, Nygreen K (2013) Educational new paternalism: human capital, cultural capital, and the politics of equal opportunity. Peabody Journal of Education 88.1:84-97

McNally D (2011) Monsters of the market: zombies, vampires, and global capitalism. Brill, Leiden and Boston

Mellor AK (1980) Mary Shelley: her life, her fiction, her monsters. Routledge, New York, NY

Mitchell R (2013) Experimental life: vitalism in romantic science. Johns Hopkins University Press, Baltimore

Mulvery-Roberts M (2016) Dangerous bodies: historicising the Gothic corporeal. Manchester University Press, Manchester

Myers RJ (1975) The cross of Frankenstein. Lippincott, Philadelphia

Newlyn L (1992) 'Paradise Lost' and the romantic reader. Clarendon Press, Oxford

NHS Digital (2017) Mental health of children and young people in England. Retrieved from https://files.digital.nhs.uk/A6/EA7D58/MHCYP\%202017\% 20Summary.pdf

O'Shea G, Jacobs T (2018). Flakensteins Snowflake students claim Frankenstein's monster was 'misunderstood'-and is in fact a VICTIM. The Sun. 5 March. Retrieved from https://www.thesun.co.uk/news/5732932/snowflake-studentsdub-frakenstein-misunderstood-victim/

Papazian G (2014) Children's literature, monsters in. In: Weinstock JA (eds) The ashgate encyclopedia of literary and cinematic monsters. Ashgate Publishing, Surrey. Retrieved from http://libezproxy.open.ac.uk/login?url=https://search. credoreference.com/content/entry/ashgtmonster/children_s_literature_ monsters_in/0?institutionId $=292$

Patel V, Flisher AJ, Hetrick S, Mcgorry P (2007) Mental health of young people: a global public-health challenge, The Lancet. Elsevier Ltd, 369.9569: 1302-1313. Retrieved from https://doi.org/10.1016/S0140-6736(07)60368-7

Paterson C, Tyler C, Lemond, J (2014) Character and resilience manifesto. All party parliamentary group. Retrieved from http://www.educationengland.org.uk/ documents/pdfs/2014-appg-social-mobility.pdf

Phillips A (2010) Multiculturalism. In: Edmonds D, Warburton N (ed). Philosophy bites. Oxford University Press, Oxford, pp. 68-76

Picart CJS (2003) Remaking the Frankenstein myth on film: between laughter and horror. State University of New York Press, New York, NY. ProQuest Ebook Central. Retrieved from https://ebookcentral.proquest.com/lib/open/detail. action?docID $=3408596$

PHE (Public Health England) (2016) The mental health of children and young people in England. Retrieved from https://assets.publishing.service.gov.uk/ government/uploads/system/uploads/attachment_data/file/575632/Mental_ health_of_children_in_England.pdf

PSHE Association (2019) Teacher guidance: teaching about mental health and emotional well-being. Retrieved from: https://www.pshe-association.org. uk/system/files/Mental\%20Health\%20guidance\%20online\%20version\%20 \%28Updated\%20July\%202019\%29.pdf

Punter D, Byron G (2004) The Gothic. Blackwell Publishing, Oxford

Rigby M (2009) Uncanny recognition: queer theory's debt to the Gothic. Gothic Studies 11.1:46-57

Royal Opera House (ROH) (2019) Frankenstein. Retrieved from: https://www.roh. org.uk/productions/frankenstein-by-liam-scarlett

Ryder R (1990) When Pigs Will Fly. In: Wheale P, McNally R (eds) The biorevolution, Cornucopias or Pandora's Box. Pluto, London, pp. 189-194
Scott N (ed) (2007) Monsters and the monstrous: myths and metaphors of enduring evil. Rodopi, Amsterdam

Seed D (1995) Anticipations: essays on early science fiction and its precursors. Liverpool University Press, Liverpool, UK

Shelley MW (1994) Frankenstein or the modern Prometheus: the 1818. Oxford University Press, Oxford, Marilyn Butler (ed)

Shelley MW (2018) Frankenstein or 'the modern Prometheus': the 1818. Oxford University Press, Oxford, Nick Groom (ed)

Smith A (2016) The Cambridge companion to Frankenstein. Cambridge University Press, Cambridge

Spendlow S (2014) Penguinpig. Mathom House Publishers, Alfreton

Sterrenburg L (1979) Mary Shelley monster: politics and psyche in Frankenstein. In: Levine G, Knoepflmacher UC (eds) The endurance of Frankenstein: essays on Mary Shelley's Novel. University of California Press, Berkeley, pp. 143-171

Struthers AE (2017) Teaching British values in our schools: but why not human rights values? Social \& Legal Studies 26.1:89-110. Retrieved from https://doi. org/10.1177/0964663916656752

Szollosy MF (2017) Frankenstein and our fear of robots: projection in our cultural perception of technology'. AI \& Society: Journal of Knowledge, Culture and Communication 32.3:433-439

Turney J (1998) Frankenstein's footsteps: science, genetics and popular culture Yale University Press, New Haven and London

UKCIS United Kingdom Council for Internet Safety (2018) Education for a connected world framework. Retrieved from https://www.gov.uk/government/ publications/education-for-a-connected-world

Vasbinder SH (1984) Scientific attitudes in Mary Shelley's Frankenstein. UMI Research Press, Ann Arbor

Weinstock JA (2014) The ashgate encyclopedia of literature and cinematic monsters. Ashgate, Farnham

Woolley R (2010) Tackling controversial issues in the primary school: facing life's challenges with your learners. Routledge, Florence, 10.4324/9780203848326

Wright A (2013) Monstrosity: the human monster in visual culture. I.B. Tauris, London and New York, NY

Wright K (ed) (2018) Introduction. Disgust and desire: the paradox of the monster Wright K (ed) Brill and Rodopi, Leiden and Boston. pp. vii-xii

Young E (2008) Black Frankenstein: the making of an American metaphor. New York University Press, New York, NY

Youngquist P (2003) Monstrosities: bodies and British romanticism. University of Minnesota Press, Minneapolis

Zylinska J (2002) Extending McLuhan into the new media age: an introduction The Cyborg experiments: the extensions of the body in the media age. Continuum, London and New York, NY, pp. 1-11

\section{Competing interests}

The authors declare no competing interests.

\section{Additional information}

Correspondence and requests for materials should be addressed to S.E.

Reprints and permission information is available at http://www.nature.com/reprints

Publisher's note Springer Nature remains neutral with regard to jurisdictional claims in published maps and institutional affiliations.

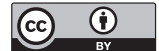

Open Access This article is licensed under a Creative Commons Attribution 4.0 International License, which permits use, sharing, adaptation, distribution and reproduction in any medium or format, as long as you give appropriate credit to the original author(s) and the source, provide a link to the Creative Commons license, and indicate if changes were made. The images or other third party material in this article are included in the article's Creative Commons license, unless indicated otherwise in a credit line to the material. If material is not included in the article's Creative Commons license and your intended use is not permitted by statutory regulation or exceeds the permitted use, you will need to obtain permission directly from the copyright holder. To view a copy of this license, visit http://creativecommons.org/ licenses/by/4.0/.

(C) The Author(s) 2020 